\title{
Studies on morphological and cultural variability of Alternaria spp. causing leaf blight in cotton
}

\author{
G. H. ANIL*, S.A. ASHTAPUTRE AND M.S.L. RAO
}

Department of Plant Pathology, University of Agricultural Sciences, DHARWAD (KARNATAKA) INDIA

\section{ARITCLE INFO}

Received : 14.06 .2017

Revised : 11.08 .2017

Accepted : 23.08.2017

\section{KEY WORDS :}

Alternaria, Cotton, Culture, Morphology, Variability

\begin{abstract}
Cotton is the most important cash crop, back bone of sprawling textile industry and fetching an export earning besides providing employment to Indian population. Alternaria a major foliar fungal pathogen showed wide variability in morphology as well as in culture. Septation of twelve isolates conidia ranged from 1-7 vertical and 3-9 horizontal. Raladoddi isolate showed maximum horizontal septa (9) and Kanakapura showed maximum vertical septa. Size of the condia varied from 132.24 x 9.10 to $14.98 \times$ 2.56, maximum size was measured in Raladoddi isolate. Measurements of all isolates were compared with standard measurements of Alternaria macrospora given by Ellis (1971), out of twelve isolates eight resembled A. macrosora. These isolates cultured on potato dextrose agar (PDA) for variability, the colony margin varied from irregular to soft, with a colour of brown, light gray and light pink. The maximum $(1.99 \mu \mathrm{m})$ width of mycelia was found in Tagalladoddi isolate.
\end{abstract}

How to view point the article : Anil, G.H., Ashtaputre, S.A. and Rao, M.S. L. (2017). Studies on morphological and cultural variability of Alternaria spp. causing leaf blight in cotton. Internat. J. Plant Protec., 10(2) : 281-290, DOI : 10.15740/HAS/IJPP/10.2/281-290. 